\title{
Comparison of Anticancer Activity of Hydroalcoholic Extracts of Curcuma longa L., Peganum harmala L., and Boswellia serrata on HeLa cells
}

\author{
Farzaneh Farajian Mashhadi, ${ }^{1,2}$ Saeedeh Salimi, ${ }^{1,3}$ Forouzan Forouzandeh, ${ }^{3,4,}{ }^{*}$ and Nooshin Naghsh ${ }^{4}$ \\ ${ }^{1}$ Cellular and Molecular Research Center, Zahedan University of Medical Sciences, Zahedan, Iran \\ ${ }^{2}$ Department of Pharmacology, School of Medicine, Zahedan University of Medical Sciences, Zahedan, Iran \\ ${ }^{3}$ Department of Clinical Biochemistry, School of Medicine, Zahedan University of Medical Sciences, Zahedan, Iran \\ ${ }^{4}$ Department of Biology, Islamic Azad University, Falavarjan Branch, Isfahan, Iran \\ "Corresponding author: Forouzan Forouzandeh, Department of Clinical Biochemistry, School of Medicine, Zahedan University of Medical Sciences, Zahedan, Iran. E-mail: \\ f.forouzanedeh@chmail.ir
}

Received 2016 February 22; Revised 2016 April 20; Accepted 2016 May 08.

\begin{abstract}
Background: Cervical cancer is the second most common cancer in women. Several native Iranian herbs used in traditional medicine are proven to have cytotoxic effects.

Objectives: The present study was designed to compare the anticancer effects of three medicinal herbs, Peganum harmala L., Curcuma longa L., and Boswellia serrata, on a cervical cancer cell line (HeLa).

Methods: HeLa cells were exposed to different doses of hydroalcoholic extracts of the three plants $(12.5,25,50,100$, and $200 \mu \mathrm{g} / \mathrm{mL})$ for $24,48,72$, and 96 hours. After the incubation period, the modified colorimetric MTT assay was used to determine cytotoxicity.

Results: The highest percentage of cell death for P. harmala was observed after 72 hours of incubation, and $50 \%$ growth inhibitory concentration (IC50) at 24 hours was $12.5 \mu \mathrm{g} / \mathrm{mL}$. For B. serrata, the highest percentage of cell death was observed after 72 hours of incubation; IC $\mathrm{IC}_{50}$ at 24 and 48 hours were $50 \mu \mathrm{g} / \mathrm{mL}$ and $12.5 \mu \mathrm{g} / \mathrm{mL}$, respectively. C. longa L. had an IC s0 $_{0}$ of $12.5 \mu \mathrm{g} / \mathrm{mL}$ after $72 \mathrm{hours}$ of incubation.

Conclusions: The results of the MTT assay showed that B. serrata and P. harmala L. extracts had time- and dose-dependent cytotoxic effects. However, $C$. longa L. extracts induced apoptosis only in a time-dependent manner. A higher cytotoxic effect was observed on HeLa cells with $P$. harmala and B. serrata extracts compared to C. longa extract at all applied concentrations.
\end{abstract}

Keywords: HeLa cell line, MTT assay, Peganum harmala L., Boswellia serrate, Curcuma longa L.

\section{Background}

Current studies on tumor-inhibiting compounds of plant origin have established alternative anticancer approaches. Various phytochemicals, such as dietary agents and nutrients, have been found to be effective against various types of malignancy. The available chemotherapeutics against cancer involve intrinsic toxicities when used in clinical settings. Agents that specifically inhibit proliferation of neoplastic cells may be valuable against cancer in humans. One approach to identifying such agents is screening plant extracts, especially those reported to have anticancer, anti-inflammatory, antibacterial, or even antifungal effects $(1,2)$.

In the present study, hydroalcoholic extracts of Curcuma longa L. (C. longa), Peganum harmala L. (P. harmala), and Boswellia serrata (B. serrata) were explored as potential sources of natural chemotherapeutic ingredients against cancer (3-6).

P. harmala Linn. (Zygophyllaceae), is a plant distributed over large areas of the world, including different parts of Iran (7). Several therapeutic effects have been attributed to P. harmala, some of which may be related to its betacarboline alkaloid content, mainly harmine and harmaline, which are both monoamine oxidase inhibitors (8) and spasmolytic (9). Harmine, the major beta-carboline alkaloid in P. harmala extract, is a DNA topoisomerase type I inhibitor (7) and a specific cyclin-dependent kinase blocker (10). It is an antileishmanial (11), anti-inflammatory (12), genotoxic (13), and recombinogenic (14) agent. It also has shown cytotoxic activity against a series of tumor cell lines (15).

For many centuries, turmeric (C. longa Linn.) has been used as a spice and as a component of many traditional medicines (16). Several studies have shown that curcumin, the active ingredient of turmeric, exhibits a wide range of pharmacological properties against many chronic diseases (17). The anticancer activity of curcumin has been extensively studied, and it has been suggested as a potential agent for both the prevention and treatment of a variety

Copyright (c) 2016, School of Pharmacy, Ahvaz Jundishapur University of Medical Sciences. This is an open-access article distributed under the terms of the Creative Commons Attribution-NonCommercial 4.0 International License (http://creativecommons.org/licenses/by-nc/4.0/) which permits copy and redistribute the material just in noncommercial usages, provided the original work is properly cited. 
of malignancies, including gastrointestinal, melanoma, genitourinary, breast, lung, hematological, head and neck, neurological, and sarcoma (18).

The gum resin of $B$. serrata has been used in traditional medicine to treat several conditions, including inflammatory and arthritic diseases (19-21). In addition to its antiinflammatory effects, a few studies showed that Boswellia may have anticancer effects on leukemia and brain tumors. Studies on tumor cells have suggested that certain components of this resin (boswellic acids) inhibit proliferation and induce apoptosis $(22,23)$.

Cervical carcinoma is one of the most common cancers in females. It has been shown that human cervical carcinoma cells maintain their functional apoptotic mechanism and respond to a wide spectrum of stimuli by going through apoptotic death $(24,25)$.

Although many studies have been published on the antineoplastic effects of $P$. harmala seed extract, $C$. longa rhizome extract, and $B$. serrata gum resin extract and their respective components, there is little information available on screening these plants with a unique method.

\section{Objectives}

In this study, the apoptotic effects of the above extracts were examined in human cervical carcinoma cells (HeLa) using the 3-(4,5-dimethylthiazol-2-yl)-2,5-diphenyl tetrazolium bromide (MTT) assay.

\section{Methods}

P. harmala seed, C. longa rhizome, and B. serrata gum resin were obtained from the Iranian institute of medicinal plants. Dimethyl sulfoxide (DMSO) was purchased from Merck (Germany). RPMI 1640 medium, MTT, and phosphate-buffered saline (PBS) were purchased from Sigma (USA). HeLa cells were purchased from the Pasteur institute, Tehran, Iran. The microplate spectrophotometer and ELISA reader were from Awareness Technology Inc. (Stat Fax 2600, USA).

The $P$. harmala seed, $C$. longa rhizome, and B. serrata gum resin were obtained as dried powders. The hydroalcoholic extracts of each plant were obtained by soaking the powders in a solvent of ethanol and water (3:1), then placing them in an oven $\left(50^{\circ} \mathrm{C}\right)$ for 72 hours. The supernatants were dried by rotary evaporation, then the cytotoxic effects of the extracts were evaluated using the HeLa cell line.

The HeLa (human epithelial cervical cancer) cells were cultured at $37^{\circ} \mathrm{C}$ with a humidified incubator at $5 \% \mathrm{CO}_{2}$, in RPMI 1640 medium containing $10 \%$ fetal calf serum and antibiotics (50 U/mL of penicillin and $50 \mu \mathrm{g} / \mathrm{mL}$ of streptomycin).

\subsection{MTT Cell Viability Assay}

In brief, the MTT assay is based on a reaction between the mitochondrial dehydrogenase enzymes from viable cells with the tetrazolium rings of MTT (a yellow reagent), which produces dark blue formazan crystals. These crystals are impermeable to cell membranes, resulting in their accumulation in healthy cells. Solubilization of the cells by adding a detergent causes the release of the crystals, which are solubilized. The number of surviving cells correlates to the level of the formazan product generated. The color can then be quantified using a colorimetric assay, and the results are read on a multi-well scanning spectrophotometer (ELISA reader).

The degree of cytotoxic activity of the extracts in the HeLa cells and normal cells was determined using the MTT assay. HeLa cells $\left(5 \times 10^{4}\right.$ cells/well) were transferred to a 96-well plate and incubated for 24 hours at $37^{\circ} \mathrm{C}$ and $5 \%$ $\mathrm{CO}_{2}$. DMSO was used to prepare different concentrations of extract $(12.5,25,50,100$, and $200 \mu \mathrm{g} / \mathrm{mL})$. Doxorubicin $200 \mu \mathrm{g} / \mathrm{mL}$ was used as a positive control. The cells were then treated with the extracts and incubated for 24, 48, 72 , or 96 hours. Then, $10 \mu \mathrm{L}$ of the MTT solution $(5 \mathrm{mg} / \mathrm{mL}$ ) was added to each well, and the plate was incubated for 3 hours. Finally, the cell culture medium of each well was discarded and $100 \mu \mathrm{L}$ of DMSO was added to dissolve the formazan crystals. Finally, microplate spectrophotometry was used to determine the absorbance at $540 \mathrm{~nm}$. The percentage of cell viability based on optical density(OD) of the treated and control cells was estimated according to the following formula:

Viability $\%=$ OD of treated cells/OD of untreated cells $\times$ 100 .

The survival curves of each cell line were established based on different concentrations of extracts after the specified time period $(24,48,72$, or 96 hours). Preliminary results showed that DMSO, used as a solvent, did not have any significant effect on cellular growth when administered alone at the concentrations used in the present experiments.

\subsection{Statistical Analysis}

For statistical analysis, all data were analyzed using SPSS statistical software, version 13.0 (SPSS, Inc., Chicago, IL, USA), and are presented as the mean \pm standard deviation. Comparisons between groups were performed using analysis of variance (ANOVA). $\mathrm{P}<0.05$ was considered to indicate a statistically significant difference. 


\section{Results}

\subsection{Effects of Time and Concentration on the Cytotoxicity of $P$.} harmala L. Extract

After 24 hours of incubation with $P$. harmala extract, the effects on cell viability were significant $(P=0.02)$ and dose-dependent. At the 48-hour incubation time, there was also a significant $(\mathrm{P}=0.003)$ decrease in the percentage of cell viability, with a dose-dependent trend (Figure 1B). When the HeLa cells were incubated for 72 hours with $P$. harmala extract, again there was a significant $(\mathrm{P}=0.002)$ dose-dependent reduction in viability, but only at concentrations lower than $50 \mu \mathrm{g} / \mathrm{mL}$ (Figure $1 \mathrm{C}$ ). After 96 hours of incubation, significantly decreased cell viability was observed only at concentrations lower than $100 \mu \mathrm{g} / \mathrm{mL}$ (Figure 1D).

Applying P. harmala extract at a concentration of 12.5 $\mu \mathrm{g} / \mathrm{mL}$ significantly decreased HeLa cell viability $(\mathrm{P}=0.04)$ (Figure $2 \mathrm{~A}$ ). At a higher concentration, $25 \mu \mathrm{g} / \mathrm{mL}$, cell viability decreased time-dependently $(\mathrm{P}=0.008)$ (Figure $2 \mathrm{~B}$ ). Using higher concentrations at 50,100, and $200 \mu \mathrm{g} / \mathrm{mL}$ also resulted in a significant time-dependent reduction in cell viability $(\mathrm{P}=0.011, \mathrm{P}=0.03$, and $\mathrm{P}=0.006$, respectively). When comparing the cell viability at each incubation time separately, the reductions were significant only with the 24 and 48 hours incubation times at concentrations of 25, 50, 100 , and $200 \mu \mathrm{g} / \mathrm{mL}$.

\subsection{Effects of Time and Concentration on the Cytotoxicity of C. longa Extract}

After 24 hours of incubation time, the viability of HeLa cells was significantly decreased $(P=0.003)$ (Figure $1 \mathrm{~A})$. There was a dose-dependent trend in viability only at 12.5 - $50 \mu \mathrm{g} / \mathrm{mL}$, and not at higher concentrations. At the 48,72 , and 96 hours incubation times, there was significantly decreased viability $(\mathrm{P}=0.002, \mathrm{P}=0.004$, and $\mathrm{P}=0.02$, respectively), with a dose-dependent trend only at low concentrations (Figure 1B, 1C, and $1 \mathrm{D}$ ).

Applying C. longa extract at concentrations of 12.5, 25 , 50, 100, and $200 \mu \mathrm{g} / \mathrm{mL}$ significantly decreased HeLa cell viability $(\mathrm{P}=0.005,0.004,0.004,0.003$, and 0.005 , respectively) (Figure 2A, 2B, 2C, 2D, and 2E).

\subsection{Effects of Time and Concentration on the Cytotoxicity of B. serrata Extract}

After 24 hours of incubation time, the viability of HeLa cells was significantly decreased $(P=0.002)$ (Figure $1 \mathrm{~A})$. There was a dose-dependent trend in viability only at 12.5 - $50 \mu \mathrm{g} / \mathrm{mL}$, and not at higher concentrations. At the 48, 72, and 96 hours incubation times, there was significantly decreased cell viability $(\mathrm{P}=0.004, \mathrm{P}=0.001$, and $\mathrm{P}=0.002$, respectively), with a dose-dependent trend only at low concentrations (Figure 1B, 1C, and 1D).

Applying B. serrata extract at concentrations of 12.5, 25, 50, 100, and $200 \mu \mathrm{g} / \mathrm{mL}$ significantly decreased Hela cell viability $(\mathrm{P}=0.06,0.004,0.004,0.004$, and 0.005 , respectively) (Figure 2A, 2B, 2C, 2D, and 2E).

The results of the present study showed that the cytotoxicity of $B$. serrata and P. harmala was significantly higher than that of $C$. longa at all concentrations at incubation times of $24,48,72$, and 96 hours. In a comparison of $B$. serrata and $P$. harmala, at 24 hours of incubation, the cytotoxicity of $P$. harmala extract was higher than that of $B$. serrata extract at all concentrations. At the 48 hours incubation time, the cytotoxicity of $B$. serrata was greater than that of P. harmala at concentrations of $12.5,25$, and $50 \mu \mathrm{g} / \mathrm{mL}$ but not at higher concentrations. At 72 and 96 hours of incubation, there was no difference in the cytotoxicity of these two extracts at any concentration.

The results of the MTT assay showed that B. serrata and $P$. harmala L. extracts had time- and dose-dependent cytotoxic effects, while $C$. longa L. induced apoptosis in a timedependent manner. The highest percentage of cell death for P. harmala was observed after 72 hours of incubation and its $\mathrm{IC}_{50}$ at 24 hours was $12.5 \mu \mathrm{g} / \mathrm{mL}$. In the case of B. serrata, the highest percentage of cell death was observed after 72 hours of incubation, and the $\mathrm{IC}_{50}$ at 24 and 48 hours was 50 and $12.5 \mu \mathrm{g} / \mathrm{mL}$, respectively. The $\mathrm{IC}_{50}$ of $\mathrm{C}$. longa was $12.5 \mu \mathrm{g} / \mathrm{mL}$ after 72 hours of incubation.

\section{Discussion}

The antitumor activity of $P$. harmala, B. serrata, and $C$. longa has drawn the attention of many researchers worldwide, leading to numerous pharmacological studies on this important effect. Harmine, the chief beta carboline alkaloid of $P$. harmala, has shown significant tumor inhibition in mice with Lewis lung carcinoma, sarcoma 180 , and HepA tumors (26), and cytotoxicity against the $\mathrm{KB}$, SaOS-2, A549, U-87-MG, and MCF-7 cell lines (27) and human lung carcinoma cell lines (28). Studies have demonstrated that these alkaloids can also act as scavengers of reactive oxygen species (29). Furthermore, studies on the mechanisms involved have indicated that beta-carboline compounds inhibit DNA topoisomerases and interfere with DNA synthesis. Some beta-carboline derivatives are specific inhibitors of cyclin-dependent kinases (CDKs), the inhibition of which may contribute to the toxicity of betacarboline derivatives (30). Cytotoxicity against tumor cells might also be attributable to the inhibition of Polo-like kinases (PLKs) (31). In a study using a luciferase-based assay in HeLa cells, targeting the transcription factor NF- $\kappa$ B showed 
A

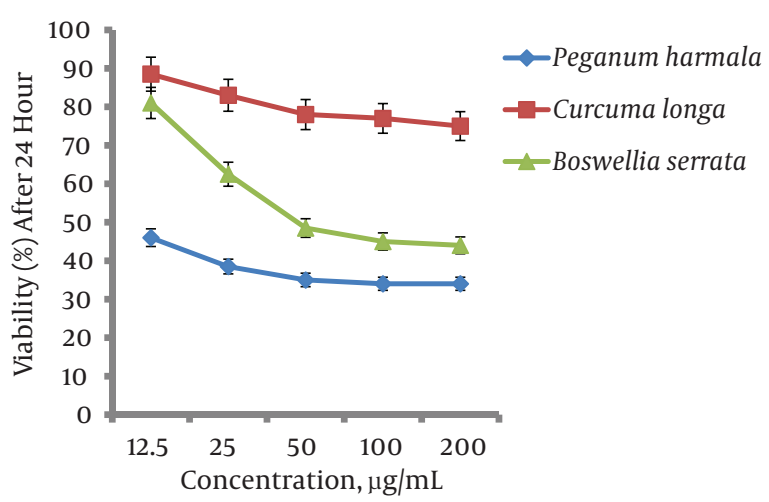

C

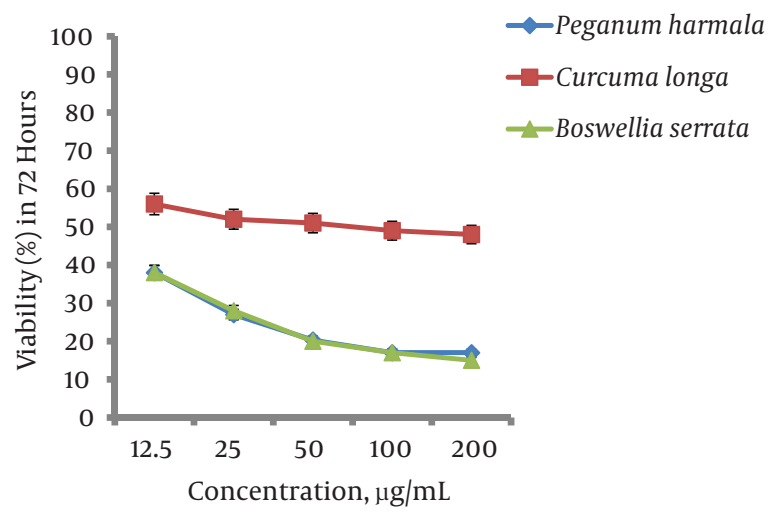

B

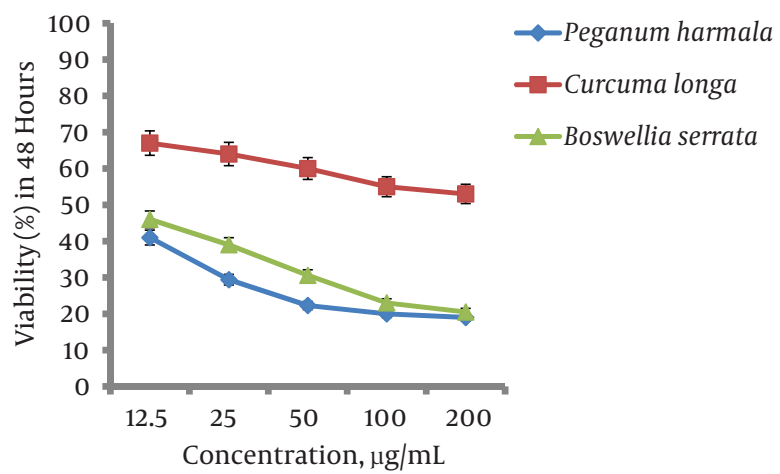

D

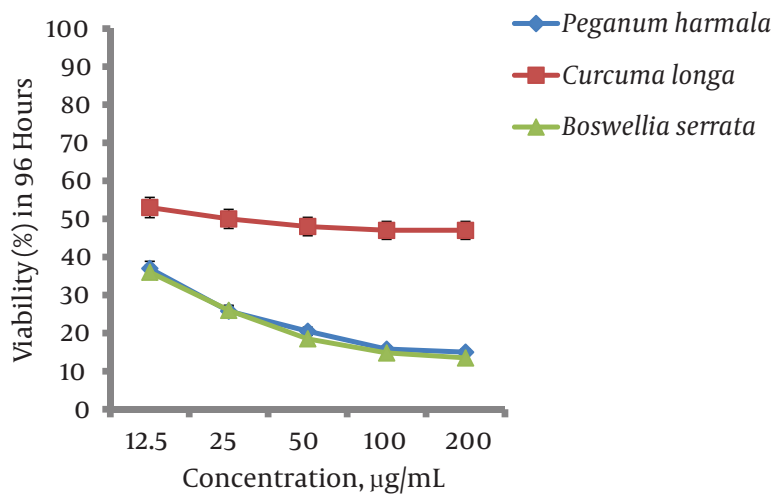

Figure 1. Effects of different concentrations of P. harmala, C. longa, and B. serrata extracts on viability (\%) of HeLa cells after incubation for A, 24 hours; B, 48 hours; C, 72 hours and D, 96 hours.

that $P$. harmala extract $(10 \mu \mathrm{g} / \mathrm{mL})$ was active at inhibiting TNF- $\alpha$ (32).

Curcumin, the major component of the spice turmeric, has been isolated from the rhizomes of $C$. longa. The antiinflammatory and cancer chemoprevention mechanisms of curcumin involve inhibitory effects on multiple signaling pathways, including COX (cycloxygenase), PKC (protein kinase $\mathrm{C}$ ), and oncogene expression, as well as on protein tyrosine kinase, arachidonic acid metabolism, and lysosomal enzyme secretion (33). In human papilloma virus (HPV)-positive HeLa, SiHa, and CaSki cervical cancer cells, curcumin mediates the inhibition of human telomerase reverse transcriptase, the catalytic core of telomerase, thereby reducing the proliferation of cancer cells. The curcumin-mediated apoptosis in these cell lines seems to be due to upregulation of proapoptotic Bax, AIF, and release of cytochrome c, and to downregulation of antiapoptotic Bcl-2 and Bcl-XL in HeLa and SiHa cells. This was accompanied by increased caspase-3 and -9 activity, indicat- ing the role of mitochondria in curcumin-mediated apoptotic cell death (34).

The gum resin of $B$. serrata has traditionally been used for the treatment of inflammatory and arthritic diseases. Several pentacyclic triterpenic acids (boswellic acids) have been isolated from the gum resin of B. serrata. Boswellic acids have consistently been reported for their antiproliferative potential in various cell systems; for instance, they were able to induce apoptosis in HL-60 cells due to the inhibition of topoisomerases I and II (35). Also, boswellic acids could stimulate cell shrinkage and phospholipid scrambling of the erythrocyte cell membrane, an effect partly dependent on p38 protein kinase activity (36). Another study showed that $B$. serrata extracts acted as cytotoxic mediators against HepG2 and HCT 116 cell lines (37), comparable to doxorubicin and 5-fluorouracil, respectively. Furthermore, in the Hela cell line, B. serrata extracts induced apoptosis in a dose-dependent manner, mainly at concentrations ranging from 0.5 to $2 \mathrm{mg} / \mathrm{mL}$ (38). 
A

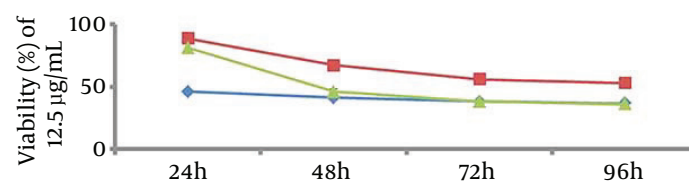

$\leadsto$ Peganum harmala

- Curcuma longa

* Boswellia serrata

B

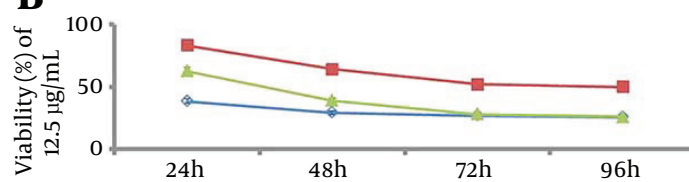

$\rightarrow$ Peganum harmala

- Curcuma longa

- Boswellia serrata

C

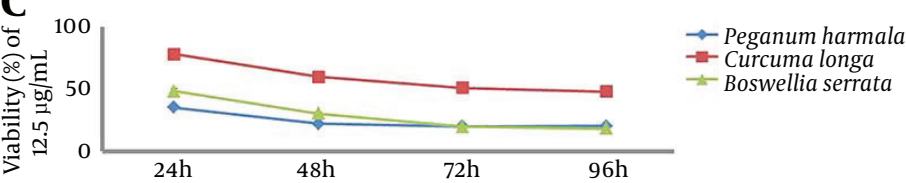

D

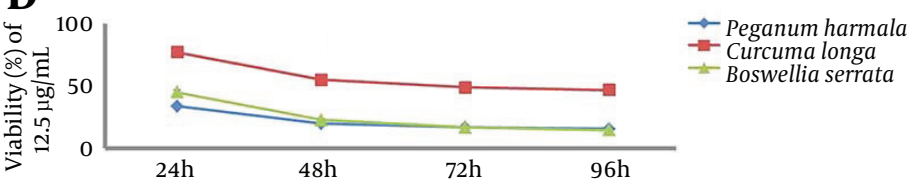

$\mathbf{E}$

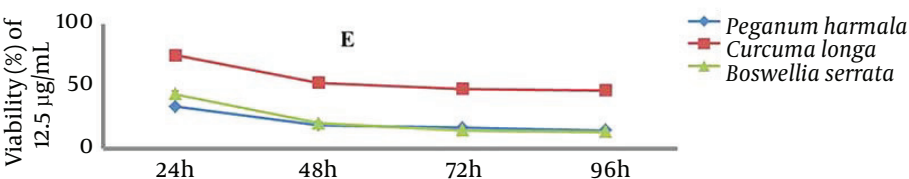

Figure 2. Effects of incubation time of P. harmala, C. longa, and B. serrata on viability (\%) of HeLa cells after incubation with different concentrations of the extracts: A, 12.5 $\mu \mathrm{g} / \mathrm{mL} ; \mathrm{B}, 25 \mu \mathrm{g} / \mathrm{mL}, \mathrm{C}, 50 \mu \mathrm{g} / \mathrm{mL} ; \mathrm{D}, 100 \mu \mathrm{g} / \mathrm{mL}$, and E, $200 \mu \mathrm{g} / \mathrm{mL}$.

In the present study, although a greater cytotoxic effect was observed with P. harmala and B. serrata extracts at lower concentrations, $C$. longa extract may benefit from being a safer compound, as it has been used as a food flavoring for many centuries. Extensive in vivo research is warranted to explore the precise bioactive natural compounds that lead to cytotoxicity against HeLa cells.

\section{Acknowledgments}

This article was extracted from an MS thesis (register number 5813) at Zahedan University of Medical Sciences. The authors thank the Zahedan deputy of research affairs for funding this project.

\section{Footnote}

Authors' Contribution: All authors contributed to this work equally.

\section{References}

1. Cordell GA, Beecher CW, Pezzuto JM. Can ethnopharmacology contribute to the development of new anticancer drugs? J Ethnopharmacol. 1991;32(1-3):117-33. [PubMed: 1881151].

2. Schnekenburger M, Dicato M, Diederich M. Plant-derived epigenetic modulators for cancer treatment and prevention. Biotechnol Adv. 2014;32(6):1123-32. doi: 10.1016/j.biotechadv.2014.03.009. [PubMed: 24699435].

3. Zikaki K, Aggeli IK, Gaitanaki C, Beis I. Curcumin induces the apoptotic intrinsic pathway via upregulation of reactive oxygen species and JNKs in H9c2 cardiac myoblasts. Apoptosis. 2014;19(6):958-74. doi: 10.1007/s10495-014-0979-y. [PubMed: 24668280].

4. Daoud A, Song J, Xiao F, Shang J. B-9-3, a novel beta-carboline derivative exhibits anti-cancer activity via induction of apoptosis and inhibition of cell migration in vitro. Eur J Pharmacol. 2014;724:219-30. doi: 10.1016/j.ejphar.2013.12.038. [PubMed: 24380828].

5. Zhang YS, Xie JZ, Zhong JL, Li YY, Wang RQ, Qin YZ, et al. Acetyl11-keto-beta-boswellic acid (AKBA) inhibits human gastric carcinoma growth through modulation of the Wnt/beta-catenin signaling pathway. Biochim Biophys Acta. 2013;1830(6):3604-15. doi: 10.1016/j.bbagen.2013.03.003. [PubMed: 23500016]. 
6. Qurishi Y, Hamid A, Sharma PR, Wani ZA, Mondhe DM, Singh SK, et al. NF-kappaB down-regulation and PARP cleavage by novel 3-alphabutyryloxy-beta-boswellic acid results in cancer cell specific apoptosis and in vivo tumor regression. Anticancer Agents Med Chem. 2013;13(5):777-90. [PubMed: 23157593].

7. Sobhani AM, Ebrahimi SA, Mahmoudian M. An in vitro evaluation of human DNA topoisomerase I inhibition by Peganum harmala L. seeds extract and its beta-carboline alkaloids. J Pharm Pharm Sci. 2002;5(1):19-23. [PubMed: 12042115].

8. Kim H, Sablin SO, Ramsay RR. Inhibition of monoamine oxidase A by beta-carboline derivatives. Arch Biochem Biophys. 1997;337(1):137-42. doi: 10.1006/abbi.1996.9771. [PubMed: 8990278].

9. Shi CC, Liao JF, Chen CF. Spasmolytic effects of three harmala alkaloids on guinea-pig isolated trachea. Pharmacol Toxicol. 2001;89(5):259-64. [PubMed: 11881980].

10. Song Y, Kesuma D, Wang J, Deng Y, Duan J, Wang JH, et al. Specific inhibition of cyclin-dependent kinases and cell proliferation by harmine. Biochem Biophys Res Commun. 2004;317(1):128-32. doi: 10.1016/j.bbrc.2004.03.019. [PubMed:15047157].

11. Di Giorgio C, Delmas F, Ollivier E, Elias R, Balansard G, TimonDavid $P$. In vitro activity of the beta-carboline alkaloids harmane, harmine, and harmaline toward parasites of the species Leishmania infantum. Exp Parasitol. 2004;106(3-4):67-74. doi: 10.1016/j.exppara.2004.04.002. [PubMed:15172213].

12. Bensalem S, Soubhye J, Aldib I, Bournine L, Nguyen AT, Vanhaeverbeek $\mathrm{M}$, et al. Inhibition of myeloperoxidase activity by the alkaloids of Peganum harmala L. (Zygophyllaceae). J Ethnopharmacol. 2014;154(2):361-9. doi: 10.1016/j.jep.2014.03.070. [PubMed: 24746482].

13. Boeira JM, da Silva J, Erdtmann B, Henriques JA. Genotoxic effects of the alkaloids harman and harmine assessed by comet assay and chromosome aberration test in mammalian cells in vitro. Pharmacol Toxicol. 2001;89(6):287-94. [PubMed: 11903953].

14. Boeira JM, Viana AF, Picada JN, Henriques JA. Genotoxic and recombinogenic activities of the two beta-carboline alkaloids harman and harmine in Saccharomyces cerevisiae. Mutat Res. 2002;500(1-2):3948. [PubMed: 11890933].

15. Lamchouri F, Zemzami M, Jossang A, Abdellatif A, Israili ZH, Lyoussi B. Cytotoxicity of alkaloids isolated from Peganum harmala seeds. PakJ Pharm Sci. 2013;26(4):699-706. [PubMed: 23811445].

16. Sharma RA, Gescher AJ, Steward WP. Curcumin: the story so far. Eur J Cancer. 2005;41(13):1955-68. doi:10.1016/j.ejca.2005.05.009. [PubMed: 16081279].

17. Aggarwal BB, Sung B. Pharmacological basis for the role of curcumin in chronic diseases: an age-old spice with modern targets. Trends Pharmacol Sci. 2009;30(2):85-94. doi: 10.1016/j.tips.2008.11.002. [PubMed: 19110321].

18. Naksuriya O, Okonogi S, Schiffelers RM, Hennink WE. Curcumin nanoformulations: a review of pharmaceutical properties and preclinical studies and clinical data related to cancer treatment. Biomaterials. 2014;35(10):3365-83. doi:10.1016/j.biomaterials.2013.12.090. [PubMed: 24439402].

19. Ammon HP. Modulation of the immune system by Boswellia serrata extracts and boswellic acids. Phytomedicine. 2010;17(11):862-7. doi: 10.1016/j.phymed.2010.03.003. [PubMed: 20696559].

20. Y J, Kamath JV, Asad M. Effect of hexane extract of Boswellia serrata oleo-gum resin on chemically induced liver damage. Pak J Pharm Sci. 2006;19(2):129-33. [PubMed: 16751123].

21. Chevrier MR, Ryan AE, Lee DY, Zhongze M, Wu-Yan Z, Via CS Boswellia carterii extract inhibits TH1 cytokines and promotes TH2 cytokines in vitro. Clin Diagn Lab Immunol. 2005;12(5):575-80. doi: 10.1128/CDLI.12.5.575-580.2005. [PubMed: 15879017].

22. Liu JJ, Nilsson A, Oredsson S, Badmaev V, Zhao WZ, Duan RD. Boswellic acids trigger apoptosis via a pathway dependent on caspase-8 activation but independent on Fas/Fas ligand interaction in colon cancer HT-29 cells. Carcinogenesis. 2002;23(12):2087-93. [PubMed: 12507932].
23. Liu JJ, Nilsson A, Oredsson S, Badmaev V, Duan RD. Keto- and acetylketo-boswellic acids inhibit proliferation and induce apoptosis in Hep G2 cells via a caspase-8 dependent pathway. Int J Mol Med 2002;10(4):501-5. [PubMed: 12239601].

24. Gruber BM, Anuszewska EL, Bubko I, Gozdzik A, Priebe W, Fokt I. Relationship between topoisomerase II-DNA cleavable complexes, apoptosis and cytotoxic activity of anthracyclines in human cervix carcinoma cells. Anticancer Res. 2005;25(3B):2193-8. [PubMed: 16158963].

25. Abraham R, Schafer J, Rothe M, Bange J, Knyazev P, Ullrich A. Identification of MMP-15 as an anti-apoptotic factor in cancer cells. J Biol Chem. 2005;280(40):34123-32. doi: 10.1074/jbc.M508155200. [PubMed: 16093241].

26. Chen Q, Chao R, Chen H, Hou X, Yan H, Zhou S, et al. Antitumor and neurotoxic effects of novel harmine derivatives and structureactivity relationship analysis. Int J Cancer. 2005;114(5):675-82. doi: 10.1002/ijc.20703. [PubMed: 15609303].

27. Ishida J, Wang HK, Bastow KF, Hu CQ, Lee KH. Antitumor agents 201. Cytotoxicity of harmine and beta-carboline analogs. Bioorg Med Chem Lett. 1999;9(23):3319-24. [PubMed: 10612592].

28. Abe A, Yamada H. Harmol induces apoptosis by caspase- 8 activation independently of Fas/Fas ligand interaction in human lung carcinoma H596 cells. Anticancer Drugs. 2009;20(5):373-81. doi: 10.1097/CAD.ob013e32832a2dd9. [PubMed:19318910].

29. Moura DJ, Richter MF, Boeira JM, Pegas Henriques JA, Saffi J. Antioxidant properties of beta-carboline alkaloids are related to their antimutagenic and antigenotoxic activities. Mutagenesis. 2007;22(4):293-302. doi: 10.1093/mutage/gem016. [PubMed: 17545209].

30. Li Y, Liang F, Jiang W, Yu F, Cao R, Ma Q, et al. DH334, a beta-carboline anti-cancer drug, inhibits the CDK activity of budding yeast. Cancer Biol Ther. 2007;6(8):1193-9. [PubMed: 17622795].

31. Zhang J, Li Y, Guo L, Cao R, Zhao P, Jiang W, et al. DH166, a betacarboline derivative, inhibits the kinase activity of PLK1. Cancer Biol Ther. 2009;8(24):2374-83. [PubMed: 19855194].

32. Bremner P, Rivera D, Calzado MA, Obon C, Inocencio C, Beckwith C, et al. Assessing medicinal plants from South-Eastern Spain for potential anti-inflammatory effects targeting nuclear factor-Kappa B and other pro-inflammatory mediators. JEthnopharmacol. 2009;124(2):295-305. doi: 10.1016/j.jep.2009.04.035. [PubMed: 19397975].

33. Shah BH, Nawaz Z, Pertani SA, Roomi A, Mahmood H, Saeed SA, et al Inhibitory effect of curcumin, a food spice from turmeric, on plateletactivating factor- and arachidonic acid-mediated platelet aggregation through inhibition of thromboxane formation and Ca2+ signaling. Biochem Pharmacol. 1999;58(7):1167-72. [PubMed:10484074].

34. Singh M, Singh N. Molecular mechanism of curcumin induced cytotoxicity in human cervical carcinoma cells. Mol Cell Biochem. 2009;325(1-2):107-19. doi: 10.1007/s11010-009-0025-5. [PubMed: 19191010].

35. Chashoo G, Singh SK, Sharma PR, Mondhe DM, Hamid A, Saxena A, et al. A propionyloxy derivative of 11-keto-beta-boswellic acid induces apoptosis in HL-60 cells mediated through topoisomerase I \& II inhibition. Chem Biol Interact. 2011;189(1-2):60-71. doi 10.1016/j.cbi.2010.10.017. [PubMed: 21056033].

36. Calabro S, Alzoubi K, Faggio C, Laufer S, Lang F. Triggering of Suicidal Erythrocyte Death Following Boswellic Acid Exposure. Cell Physiol Biochem. 2015;37(1):131-42. doi: 10.1159/000430339. [PubMed: 26303375]

37. Ahmed HH, Abd-Rabou AA, Hassan AZ, Kotob SE. Phytochemical Analysis and Anti-cancer Investigation of Boswellia serrata Bioactive Constituents In Vitro. Asian Pac JCancerPrev. 2015;16(16):7179-88. [PubMed: 26514509].

38. Kim HR, Kim MS, Kwon DY, Chae SW, Chae HJ. Bosellia serrata-induced apoptosis is related with ER stress and calcium release. Genes Nutr. 2008;2(4):371-4. doi: 10.1007/s12263-007-0072-z. [PubMed:18850233]. 